five tons. Recent archæological discovery, notably in Yorkshire, at Colchester and most recently at Lincoln, have made familiar the kiln and mode of firing employed by the Romano-British potter; but as a rule the conditions of discovery have precluded preservation for general inspection. The kiln now on view at the Science Museum is the only example of the period exhibited in Great Britain.

\section{Exhibition of Kinematography}

THE fourth Exhibition of Kinematography, arranged by the Royal Photographic Society, was opened at the Society's premises, 35 Russell Square, London, on November 28 and will remain open until December 19. A large selection of still pictures illustrates the ever-widening scope of kinematography, and includes examples of the work of many producing companies and amateur societies, and of films-scientific, instructional and for purposes of entertainment and publicity. Much recent apparatus, standard and sub. standard, is on view, this section including exhibits by most of the leading manufacturers. A Vinten gyroscopic tripod for $16-\mathrm{mm}$. work is particularly worthy of note. Stock manufacturers are also to the fore. Kodachrome is being exhibited in $16-\mathrm{mm}$. and $8-\mathrm{mm}$. sizes, the smaller size being not yet on the market in Great Britain. On this stand, too, Messrs. Kodak show samples of $16 \cdot \mathrm{mm}$. work with Pola screens, Messrs. Ilford have staged an exhibit with photographs illustrating the manufacture and testing of Cine products. Examples of their various products, including Dufaycolor, are on view. A comprehensive programme of lectures has been arranged on subjects varying from sound recording to the making of cartoon films. No charge is made for admission to the Exhibition, to the meetings, or for reserving seats.

\section{Dr. E. Bausch and the Optical Industry of America}

The American Society of Mechanical Engineers made its annual awards for distinguished service in engineering and science, and "for great and unique acts of an engineering nature that have accomplished a great and timely benefit to the public" on December 1 to Dr. Edward Bausch and Mr. Henry Ford, when Dr. Bausch received the A.S.M.E. Medal and Mr. Ford the Holley Medal, the former established in 1920 and the latter in 1923. The A.S.M.E. Medal is awarded once a year, "and that only for inventions and improvements of great merit in the technical and public sense". Among the previous recipients have been H. G. Carlson, Dr. Robert A. Millikan, Dr. Ambrose Swasey, and other distinguished contributors to the progress of engineering. In his long and notable career, which began with the construction of his first microscope in 1872, Dr. Bausch has been a constant contributor to engineering progress. At eighty-three years of age, he is still at work, and recently, with other members of the Bausch and Lomb Optical Co., has designed the contour measuring projector. This new instrument is proving itself a valuable inspection device in many types of industry. It is both a microscope and a projection apparatus of the highest quality and great accuracy with which a highly magnified profile of such parts as screw threads, gears, dies, gauges and shapers may be thrown upon a screen or chart for study and comparison.

Dr. BAUSCH entered his company's service sixty. two years ago, immediately upon leaving Cornell University. As assistant to his father, John J. Bausch, he is credited with the great expansion of the industry in the United States through the introduction of new technical methods and machine processes to compete with the cheaper hand labour of Europe. Dr. Bausch has for many years been a fellow of the Royal Microseopical Society, and has a wide acquaintance with workers in this field both in Europe and the United States. Not content with his own efforts in building up the optical industry, Dr. Bausch has been conscious of the necessity of educational work to perpetuate his labours. This explains his interest in the establishment of the Institute of Optics, as a part of the Physics Department of the University of Rochester, and the construction of the Bausch and Lomb Physies Building at the University in honour of his father and Captain Henry Lomb, founders of the Bausch and Lomb Optical Co.

\section{Research on Atmospheric Pollution}

THIRTY.THREe representatives of local authorities and other organizations co-operating with the Department of Scientific and Industrial Research met at the Fuel Research Station of the Department at East Greenwich on November 30 to discuss the investigation of atmospheric pollution. Dr. G. M. B. Dobson, chairman of the Atmospheric Pollution Research Committee, presented a report on the progress of the investigations carried out under the auspices of the Committee. The Conference noted especially that arrangements are well in hand for the intensive survey of pollution in and around Leicester. After the meeting, the representatives were shown the work of interest to them which is in progress at the Fuel Research Station. Broadly speaking, there are two fundamental and closely related factors involved in the reduction of atmospheric pollution by coal burning-the nature of the fuel and the appliance in which it is burned. The former of these leads to the selection from the varieties available of fuel most suitable for a given purpose. The preparation of coal for the market, by cleaning and grading, assists materially in the reduction of pollution; the cleaning yields a coal of lower ash content, thus decreasing the potential emission of ash in the form of grit, while grading the coal according to size reduces the content of small particles which may be blown from the fuel bed by the draught. The aim in coal-burning appliances is towards greater control over the combustion. This is obtained by uniform air distribution to the fuel and the regulation of air supply, thereby promoting efficient combustion and a reduction of the unburned products passing into the atmosphere. In the domestic field attention has been devoted mainly to the production from coal of a 